\title{
Spur cell anemia related to alcoholic liver cirrhosis managed without liver transplantation: a case report and literature review
}

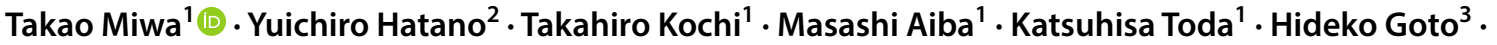 \\ Noriaki Nakamura ${ }^{1} \cdot$ Naoki Katsumura $^{1} \cdot \mathrm{Kenji}_{\text {Imai }}{ }^{4}$ Masahito Shimizu ${ }^{4}$
}

Received: 19 November 2019 / Accepted: 20 May 2020 / Published online: 29 May 2020

(c) Japanese Society of Gastroenterology 2020

\begin{abstract}
Spur cell anemia is an acquired hemolytic anemia associated with liver cirrhosis and is characterized by the presence of increased large red blood cells, which are covered with spike-like projections that vary in width, length, and distribution. A 26-year-old man was referred to our hospital presenting with jaundice, lower limb edema, and dyspnea. The patient was subsequently diagnosed with spur cell anemia related to alcoholic liver cirrhosis. Spur cell anemia is an independent predictor of mortality in liver cirrhosis and has been associated with extremely poor prognosis. The most effective treatment for spur cell anemia is liver transplantation. As seen in the literature, the treatment of spur cell anemia without liver transplantation is quite challenging. This report highlights the importance of management and treatment strategies, including control of fluid retention, blood transfusion, plasma diafiltration, and administration of diuretics. Our treatment strategies might be useful in patients who are not candidate of liver transplantation or patients waiting for liver transplantation.
\end{abstract}

Keywords Alcoholic liver cirrhosis $\cdot$ Case report $\cdot$ Liver cirrhosis $\cdot$ Plasma diafiltration $\cdot$ Spur cell anemia

\section{Introduction}

Anemia of diverse etiology is commonly seen in patients with liver cirrhosis. Causes of anemia related to liver cirrhosis are complex and multifactorial. Gastrointestinal hemorrhage secondary to the formation of esophageal and gastric varices, thrombocytopenia, and coagulation disorders are some of the major and life-threatening causes of anemia in liver cirrhosis [1, 2]. In addition, in patients with cirrhosis, portal hypertension gastropathy and gastric vascular ectasia are common causes of chronic anemia [3]. Gastrointestinal hemorrhage may also lead to iron-deficiency anemia in cirrhosis [4]. Hemolysis secondary to splenomegaly, caused by

Takao Miwa

takao.miwa0505@gmail.com

1 Department of Gastroenterology, Chuno Kosei Hospital, 5-1 Wakusadori, Seki, Gifu 501-3802, Japan

2 Department of Tumor Pathology, Gifu University Graduate School of Medicine, Gifu, Japan

3 Department of Hematology, Chuno Kosei Hospital, Gifu, Japan

4 Department of Gastroenterology, Gifu University Graduate School of Medicine, Gifu, Japan portal hypertension, may lead to increased plasma volume, macrocytosis, and megaloblastic anemia [5]. In addition, autoimmune hemolytic anemia associated with autoimmune hepatitis [6], Wilson's disease with increased non-ceruloplasmin-bound copper released from impaired hepatocytes [7], Zieve's syndrome [8], and spur cell anemia (SCA) [9] are all causes of hemolytic anemia associated with liver disease. Aplastic anemia, characterized by the development of pancytopenia and hypocellular bone marrow, is sometimes associated with hepatitis [10]. Alcoholic liver disease is one of the major causes of liver cirrhosis. Alcohol is known to be toxic to the bone marrow, and up to $60 \%$ of alcoholics with cirrhosis also have some degree of malnutrition, which may lead to anemia (e.g., folic acid deficiency, vitamin B12 deficiency) [11] (Table 1).

SCA is an acquired hemolytic anemia associated with liver cirrhosis and characterized by the presence of increased large red blood cells which are covered with spike-like projections that vary in width, length, and distribution. SCA was first reported in 1964 [9, 12]. The prognosis of SCA is extremely poor and liver transplantation is the only curative treatment [13-17]. The treatment of SCA without liver transplantation is quite challenging. We herein report a case 
Table 1 Causes of anemia related to liver disease

\begin{tabular}{lc}
\hline Cause of anemia related to liver disease & References \\
\hline 1. Gastrointestinal bleeding & {$[1,3]$} \\
$\begin{array}{l}\text { a. Esophageal varices, gastric varices, gastric vascular ectasia, etc } \\
\text { b. Thrombocytopenia, coagulation disorder }\end{array}$ \\
$\begin{array}{l}\text { 2. Hemolysis } \\
\text { a. Hypersplenism secondary to portal hypertension }\end{array}$ \\
$\begin{array}{l}\text { b. Autoimmune hemolytic anemia associated with autoimmune hepatitis } \\
\text { c. Wilson's disease with increased non-ceruloplasmin-bound copper }\end{array}$ \\
$\begin{array}{l}\text { d. Zieve's syndrome, spur cell anemia } \\
\text { 3. Aplastic anemia associated with hepatitis }\end{array}$ \\
$\begin{array}{l}\text { 4. Alcohol } \\
\text { a. Bone marrow toxicity }\end{array}$ \\
b. Malnutrition (e.g. folic acid deficiency, vitamin B12 deficiency)
\end{tabular}

of SCA related to alcoholic liver disease, which was successfully controlled by intensive care management.

\section{Case report}

A 26-year-old man was referred to our hospital presenting jaundice, lower limb edema, and dyspnea. He had a drinking history of 200-300 g alcohol per day since 20 years of age. Laboratory test and computed tomography (CT) a year prior to hospitalization showed alcoholic liver disease without decompensated liver cirrhosis. The patient had no familial predisposition to the disease and no past surgical history, history of pancreatitis, or history of blood transfusion. He had jaundice, lower limb edema, and dyspnea since 2 months prior to hospital referral. Despite the progressive increase in symptoms, he did not stop drinking until 1 week prior to referral, by which time he had difficulty in walking due to the lower limb edema and dyspnea. He then visited another hospital before being referred to our hospital. At the time of arrival, the patient was jaundiced, had conjunctival anemia and systemic edema which was especially severe in the lower limbs. The patient was also hypoxemic, and was administered nasal oxygen at $2 \mathrm{~L} / \mathrm{min}$. Laboratory test (Table 2) results revealed severe liver dysfunction [Child-Pugh score 11 points, Model for End-stage Liver Disease (MELD) score 24 points, MELD-Na score 28 points] with a total bilirubin of $12.7 \mathrm{mg} / \mathrm{dL}$, direct bilirubin of $5.4 \mathrm{mg} / \mathrm{dL}$, prothrombin time of $30 \%$, and Mac-2 binding protein glycan isomer of 12.16 COI. Brain natriuretic peptide levels were elevated. In addition, the patient had a hemoglobin level of $2.1 \mathrm{~g} / \mathrm{dL}$ with macrocytic anemia, and a peripheral blood smear revealed the presence of a large number of spur cells (Fig. 1). Haptoglobin was decreased, despite direct and indirect Coombs tests results being normal. No abnormality was detected in upper gastrointestinal endoscopy and bone marrow examination. Chest $\mathrm{CT}$ revealed pleural effusion and ground-glass opacity with partial consolidation, suggesting pulmonary edema (Fig. 2a), whilst contrast CT of the abdomen and pelvis revealed chronic liver disease and ascites estimated to be less than $1 \mathrm{~L}$ without portal vein thrombosis or hepatocellular carcinoma (Fig. 2b). Pathological findings of liver biopsy were consistent with advanced alcoholic liver cirrhosis (Fig. 3a-c).

With presence of spur cells in the peripheral blood smear, laboratory test, liver biopsy, and exclusion of other causes of anemia and liver disease, the patient was diagnosed with SCA related to alcoholic liver cirrhosis. He was administered a blood transfusion as part of the treatment regimen. In addition, he was supplemented with branched-chain amino acid, levocarnitine, rifaximin, zinc, folic acid, vitamin B1, vitamin B6, vitamin B12, vitamin $\mathrm{C}$, and vitamin $\mathrm{B} 12$. Whilst treatment, $\mathrm{PaO}_{2} / \mathrm{FiO}_{2}$ ratio decreased to 100 and the diagnosis of acute pulmonary respiratory distress was established, so a decision was made to intubate the patient. Hemoglobin level modification was necessary to improve oxygenation. Large amounts of blood transfusions were thought to worsen pulmonary edema, so plasma diafiltration (PDF) was performed during blood transfusion. The $\mathrm{PaO}_{2} / \mathrm{FiO}_{2}$ ratio improved to $>200$, and the furosemide dose was increased to decrease pulmonary edema. The patient experienced a rapid decrease in body weight and was consequently weaned off from ventilatory support. Although MELD score did not improve, there was improvement in anemia and respiratory failure (Fig. 4). The patient was discharged and advised to abstain from alcohol. Laboratory test at the time of discharge showed improvement of hemoglobin level $(\mathrm{Hb} 8.7 \mathrm{~g} / \mathrm{dL})$ and slight improvement of bilirubin level (Total-bilirubin $9.5 \mathrm{mg} /$ $\mathrm{dL}$, Direct-bilirubin $3.7 \mathrm{mg} / \mathrm{dL}$ ). Liver function was also improved compared to that on admission (Child-Pugh score 9 points, MELD score 19 points, MELD-Na score 23 points). CT at the time of discharge revealed recovery of pleural effusion and consolidation (Fig. 5a). Subcutaneous 
Table 2 Laboratory data on admission

\begin{tabular}{|c|c|c|c|c|c|c|c|c|}
\hline \multicolumn{3}{|l|}{$<$ Peripheral blood $>$} & \multirow{2}{*}{$\frac{\gamma \text {-GTP }}{\mathrm{ChE}}$} & \multirow{2}{*}{$\frac{208}{102}$} & \multirow{2}{*}{$\frac{\mathrm{U} / \mathrm{L}}{\mathrm{U} / \mathrm{L}}$} & \multirow{2}{*}{$\begin{array}{l}\text { Haptoglobin } \\
\text { ANA }\end{array}$} & \multirow{2}{*}{$\frac{<10}{<40}$} & \multirow{2}{*}{$\frac{\mathrm{mg} / \mathrm{dL}}{\times}$} \\
\hline WBC & 4900 & $/ \mu \mathrm{L}$ & & & & & & \\
\hline Neutro & 59.2 & $\%$ & T-chol & 215 & $\mathrm{mg} / \mathrm{dL}$ & AMA (M2) & $(-)$ & \\
\hline Eosi & 0.2 & $\%$ & $\mathrm{TG}$ & 83 & $\mathrm{mg} / \mathrm{dL}$ & Intrinsic factor $\mathrm{Ab}$ & $(-)$ & \\
\hline Baso & 0.2 & $\%$ & HDL-chol & 39 & $\mathrm{mg} / \mathrm{dL}$ & Gastric Parietal Cell Ab & $(-)$ & \\
\hline Lym & 30.7 & $\%$ & LDL-chol & 56 & $\mathrm{mg} / \mathrm{dL}$ & $<$ Tumor markers $>$ & & \\
\hline Mono & 9.7 & $\%$ & UA & 7.6 & $\mathrm{mg} / \mathrm{dL}$ & AFP & 5.9 & $\mathrm{ng} / \mathrm{mL}$ \\
\hline $\mathrm{RBC}$ & $41 \times 10^{4}$ & $/ \mu \mathrm{L}$ & BUN & 7.1 & $\mathrm{mg} / \mathrm{dL}$ & PIVKA-II & 6033 & $\mathrm{ng} / \mathrm{mL}$ \\
\hline $\mathrm{Hb}$ & 2.1 & $\mathrm{~g} / \mathrm{dL}$ & $\mathrm{Cr}$ & 0.41 & $\mathrm{mg} / \mathrm{dL}$ & $<$ Viral markers $>$ & & \\
\hline $\mathrm{Ht}$ & 6.2 & $\%$ & $\mathrm{NH}_{3}$ & 70 & $\mu \mathrm{g} / \mathrm{dL}$ & IgM-HA Ab & $(-)$ & \\
\hline $\mathrm{MCV}$ & 151.2 & $\mathrm{fl}$ & $\mathrm{Na}$ & 131 & $\mathrm{mEq} / \mathrm{L}$ & HBs-Ag & $(-)$ & \\
\hline $\mathrm{MCH}$ & 51.2 & $\mathrm{pg}$ & $\mathrm{K}$ & 2.8 & $\mathrm{mEq} / \mathrm{L}$ & HBs-Ab & $(-)$ & \\
\hline $\mathrm{MCHC}$ & 33.9 & $\%$ & $\mathrm{Cl}$ & 92 & $\mathrm{mEq} / \mathrm{L}$ & $\mathrm{HBc}-\mathrm{Hb}$ & $(-)$ & \\
\hline Plt & $10.7 \times 10^{4}$ & $/ \mu \mathrm{L}$ & $\mathrm{Fe}$ & 146 & $\mu \mathrm{g} / \mathrm{dL}$ & HBV-DNA (PCR) & $(-)$ & \\
\hline Ret & 5 & $\%$ & UIBC & 12 & $\mu \mathrm{g} / \mathrm{dL}$ & $\mathrm{HCV}-\mathrm{Ab}$ & $(-)$ & \\
\hline$<$ Coagulation $>$ & & & Ferritin & 1020 & $\mathrm{ng} / \mathrm{mL}$ & HCV-RNA (PCR) & $(-)$ & \\
\hline PT & 30 & $\%$ & Vit. $\mathrm{B}_{12}$ & 1500 & $\mathrm{pg} / \mathrm{mL}$ & IgA-HEV & $(-)$ & \\
\hline PT-INR & 2.11 & & Folic acid & 22 & $\mathrm{pg} / \mathrm{mL}$ & IgM-CMV & $(-)$ & \\
\hline APTT & 37 & $\mathrm{~s}$ & $\mathrm{Cu}$ & 90 & $\mu \mathrm{g} / \mathrm{dL}$ & EBV VCA-IgM & $<10$ & $x$ \\
\hline FIB & 123 & $\mathrm{mg} / \mathrm{dL}$ & $\mathrm{Zn}$ & 41 & $\mu \mathrm{g} / \mathrm{dL}$ & EBV VCA-IgG & 80 & $\times$ \\
\hline FDP & 37.1 & $\mu \mathrm{g} / \mathrm{mL}$ & CRP & 1.09 & $\mu \mathrm{g} / \mathrm{dL}$ & EBNA & $<10$ & $\times$ \\
\hline D-dimer & 13 & $\mu \mathrm{g} / \mathrm{mL}$ & HGF & 0.75 & $\mathrm{ng} / \mathrm{mL}$ & $<$ Coombs test $>$ & & \\
\hline ATIII & 47 & $\%$ & M2BPGi & 12.16 & $\mathrm{COI}$ & Direct & $(-)$ & \\
\hline$<$ Biochemistry $>$ & & & Hyaluronic acid & 4050 & $\mathrm{ng} / \mathrm{mL}$ & Indirect & $(-)$ & \\
\hline $\mathrm{TP}$ & 5.9 & $\mathrm{~g} / \mathrm{dL}$ & Type IV collagen & 19 & $\mathrm{ng} / \mathrm{mL}$ & $<$ Urinalysis $>$ & & \\
\hline Alb & 3.0 & $\mathrm{~g} / \mathrm{dL}$ & BTR & 3.75 & & Protein & $(+++)$ & \\
\hline T-Bill & 12.7 & $\mathrm{mg} / \mathrm{dL}$ & BNP & 874.8 & $\mathrm{pg} / \mathrm{mL}$ & Sugar & $(-)$ & \\
\hline D-Bill & 5.4 & $\mathrm{mg} / \mathrm{dL}$ & KL-6 & 279 & $\mathrm{U} / \mathrm{mL}$ & Occult blood & $(+)$ & \\
\hline AST & 58 & $\mathrm{U} / \mathrm{L}$ & $<$ Immunology $>$ & & & Urobilinogen & $(++)$ & \\
\hline ALT & 18 & $\mathrm{U} / \mathrm{L}$ & $\operatorname{IgG}$ & 1569 & $\mathrm{mg} / \mathrm{dL}$ & Bilirubin & $(+)$ & \\
\hline LDH & 449 & $\mathrm{U} / \mathrm{L}$ & $\operatorname{Ig} \mathrm{A}$ & 254 & $\mathrm{mg} / \mathrm{dL}$ & WBC & $(-)$ & \\
\hline ALP & 175 & $\mathrm{U} / \mathrm{L}$ & $\operatorname{IgM}$ & 87 & $\mathrm{mg} / \mathrm{dL}$ & & & \\
\hline
\end{tabular}

WBC white blood cell, Neutro neutrophil, Eosi eosinophil, Baso basophil, Lyn lymphocyte, Mono monocyte, Ret reticulocyte, RBC red blood cell, $H t$ hematocrit, $M C V$ mean corpuscular volume, $M C H C$ mean corpuscular hemoglobin concentration, Plt platelet, $P T$ prothrombin time, $I N R$ international normalized ratio, APTT active partial thromboplastin time, FIB fibrinogen, FDP fibrin and fibrinogen degradation products, $A T I I I$ antithrombinIII, $T P$ total protein, Alb albumin, $T$-Bill total bilirubin, $D$-bill direct bilirubin, $A S T$ aspartate aminotransferase, $A L T$ alanine aminotransferase, $L D H$ lactate dehydrogenase, $A L P$ alkaline phosphatase, GTP glutamyl transferase, $C h E$ cholinesterase, $T$-chol total cholesterol, $T G$ triglyceride, $H D L$-chol high-density lipoprotein cholesterol, $L D L$-chol low-density lipoprotein cholesterol, $U A$ uric acid, $B U N$ blood urea nitrogen, $\mathrm{Cr}$ creatinine, $\mathrm{NH}_{3}$ ammonia, $\mathrm{Na}$ natrium, $\mathrm{K}$ kalium, $\mathrm{Cl}$ chloride, $\mathrm{Fe}$ ferrum, $\mathrm{UIBC}$ unsaturated iron-binding capacity, $\mathrm{Vit}$ vitamin, $\mathrm{Cu}$ copper, $Z u$ zinc, $C R P$ C-reactive protein, $H G F$ hepatocyte growth factor, $M 2 B P G i$ mac-2-binding protein glycan isomer, $B T R$ ratio of branchedchain amino acid to tyrosine, $B N P$ brain natriuretic peptide, $K L-6$ Krabs von den Lungen-6, $A N A$ anti-nuclear antibody, $A M A$ anti-mitochondrial antibody, $A F P$ alfa-fetoprotein, PIVKA-II protein-induced by vitamin $\mathrm{K}$ absence or antagonist-II, $H A A b$ hepatitis A antibody, $H B s-A g$ hepatitis B surface antigen, $H B s-A b$ hepatitis B surface antibody, $H B c-A b$ hepatitis B core antibody, $H B V-D N A$ hepatitis B virus deoxyribonucleic acid, $P C R$ polymerase chain reaction, $H C V$ - $A b$ hepatitis $\mathrm{C}$ virus antibody, $H C V-R N A$ hepatitis $\mathrm{C}$ virus ribonucleic acid, $H E V$ hepatitis $\mathrm{E}$ virus, $C M V$ cytomegalovirus, $E B V V C A-I g M A b$ epstein-barr virus-viral capsid antigen immunoglobulin $\mathrm{M}$ antibody, $E B V V C A-I g G A b$ epstein-barr virus viral capsid antigen immunoglobulin $\mathrm{G}$ antibody, EBNA epstein-barr virus nuclear antigen

edema was remarkably improved, without obvious change in liver shape (Fig. 5b). A year on from initial hospitalization, MELD score and spur cell rate in peripheral blood smear did not improve. Though, the patient succeeded in abstaining from alcohol and is doing well without exacerbation of hemoglobin level.

\section{Discussion}

Several abnormal red blood cells such as acanthocytes, echinocytes, target cells, stomatocytes, and spur cells are seen in patients with liver cirrhosis [17]. Although the precise mechanism is unknown, the central role of abnormal lipid 


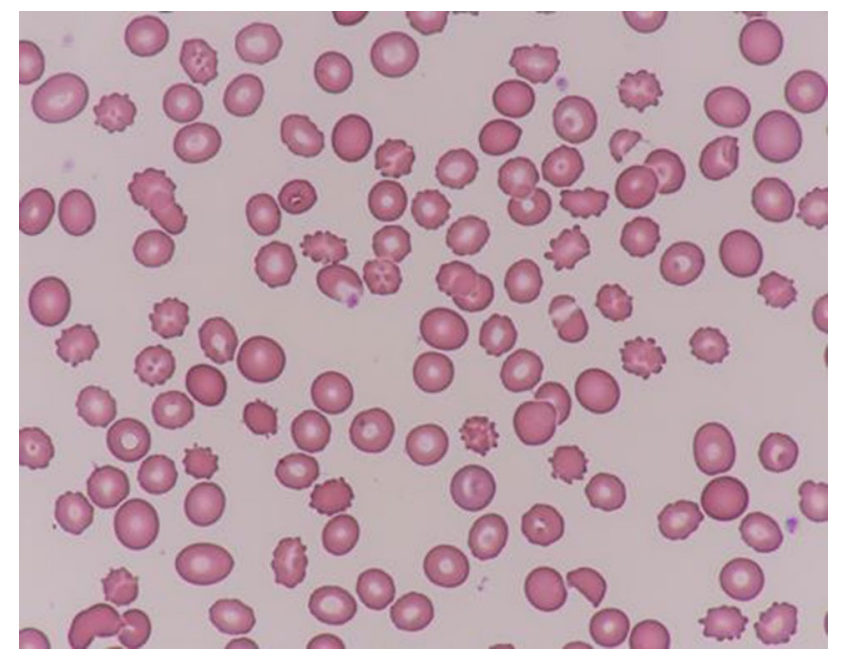

Fig. 1 Peripheral blood smear (May-Giemsa stain, $\times 1000$ ) revealed approximately $25 \%$ of spur cells with multiple spicules irregularly distributed over the red blood cell

metabolism in the formation of abnormal red blood cells (including spur cells and target cells) has been demonstrated by in vitro observation [18]. SCA was originally reported as a severe form of hemolytic anemia, with the presence of spur cells on a peripheral blood smear [9]. Recently, various etiologies of liver cirrhosis were reported as causes of SCA, which is shown to occur in any etiology of liver cirrhosis [19-21]. The precise mechanism of SCA in liver cirrhosis is still unknown, although abnormal ratio of cholesterol and phospholipids in red blood cell membrane is thought to be the main cause of SCA $[9,15]$. According to previous reports, the diagnosis of SCA differ [9, 12, 15, 17, 22]. In a recent study, patients presenting with $>5 \%$ spur cells in peripheral blood were diagnosed with SCA [22]. In addition, the exclusion of other causes of anemia is an essential

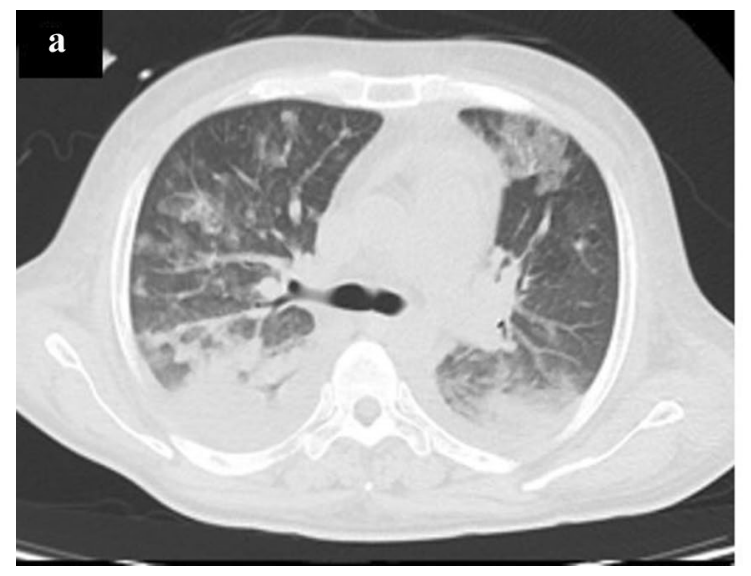

Fig. 2 a Chest computed tomography (CT) revealed pleural effusion and ground-glass opacity with partial consolidation suspecting pulmonary edema. b Contrast CT of the abdomen and pelvis revealed
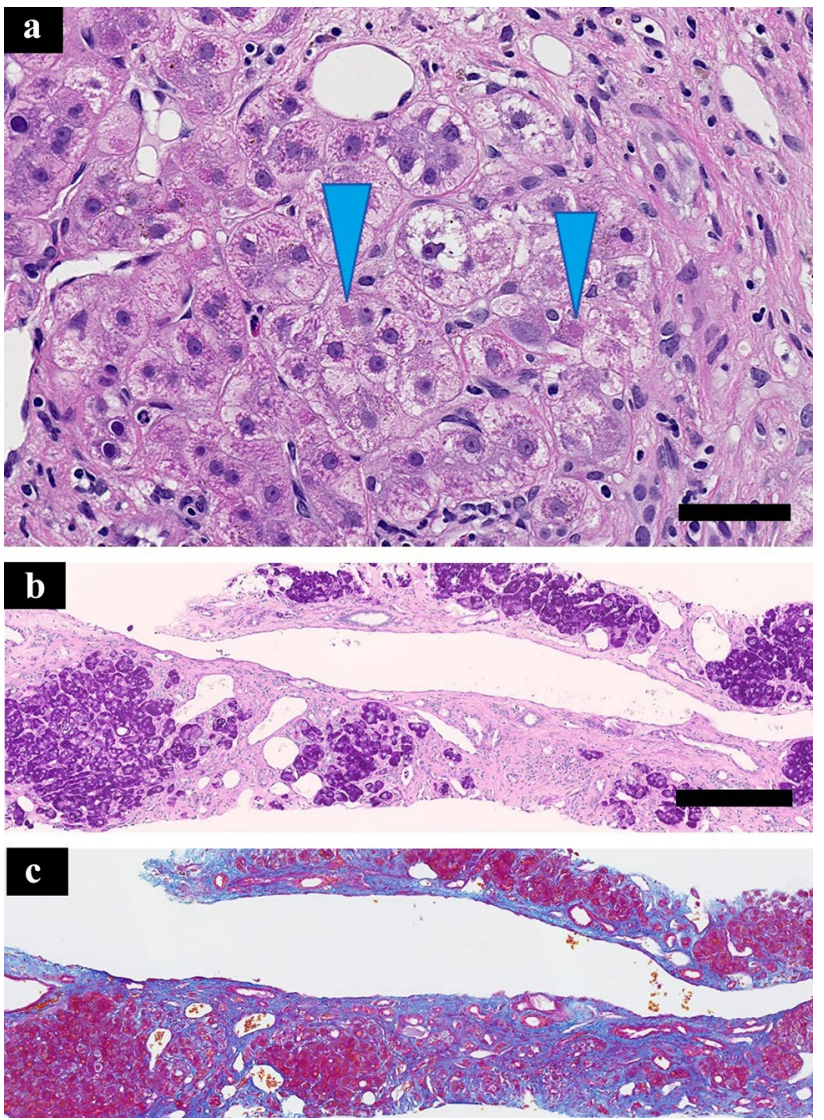

Fig. 3 Pathological findings of liver biopsy. a (hematoxylin and eosin stain, scale bar: $50 \mu \mathrm{m}$ ): hematoxylin and eosin stain shows hepatocellular ballooning and Mallory bodies (blue arrowhead). b (periodic acid-Schiff stain, scale bar: $250 \mu \mathrm{m}$ ), c (Azan stain, scale: same as b): periodic acid-Schiff stain and Azan stain show lobular distortion with scattered small hepatic cell nests. Note that fatty change of hepatocyte is minimal

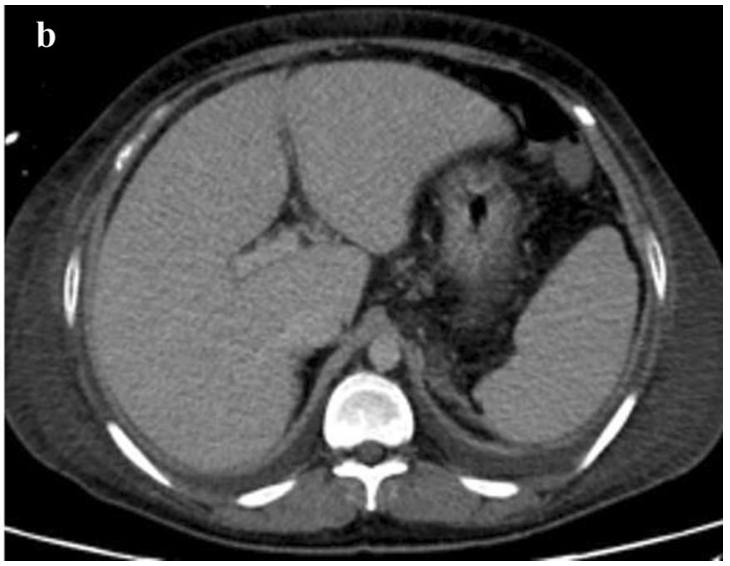

chronic liver disease and ascites estimated to be less than $1 \mathrm{~L}$ without portal vein thrombosis or hepatocellular carcinoma 
Fig. 4 Blood transfusion and fluid retention aggravated $\mathrm{PaO}_{2} /$ $\mathrm{FiO}_{2}$ ratio. Intubation, plasma diafiltration (PDF) during blood transfusion, high-dose diuretics improved anemia, oxygenation, and body weight. Without liver transplantation, Model for End-stage Liver Disease (MELD) score and presence of spur cell in peripheral blood smear did not improve, although symptoms related to anemia and liver cirrhosis were successfully managed. FFP fresh frozen plasma, MELD Model for End-stage Liver Disease, $P D F$ plasma diafiltration, $R B C$ red blood cell, $U$ Unit
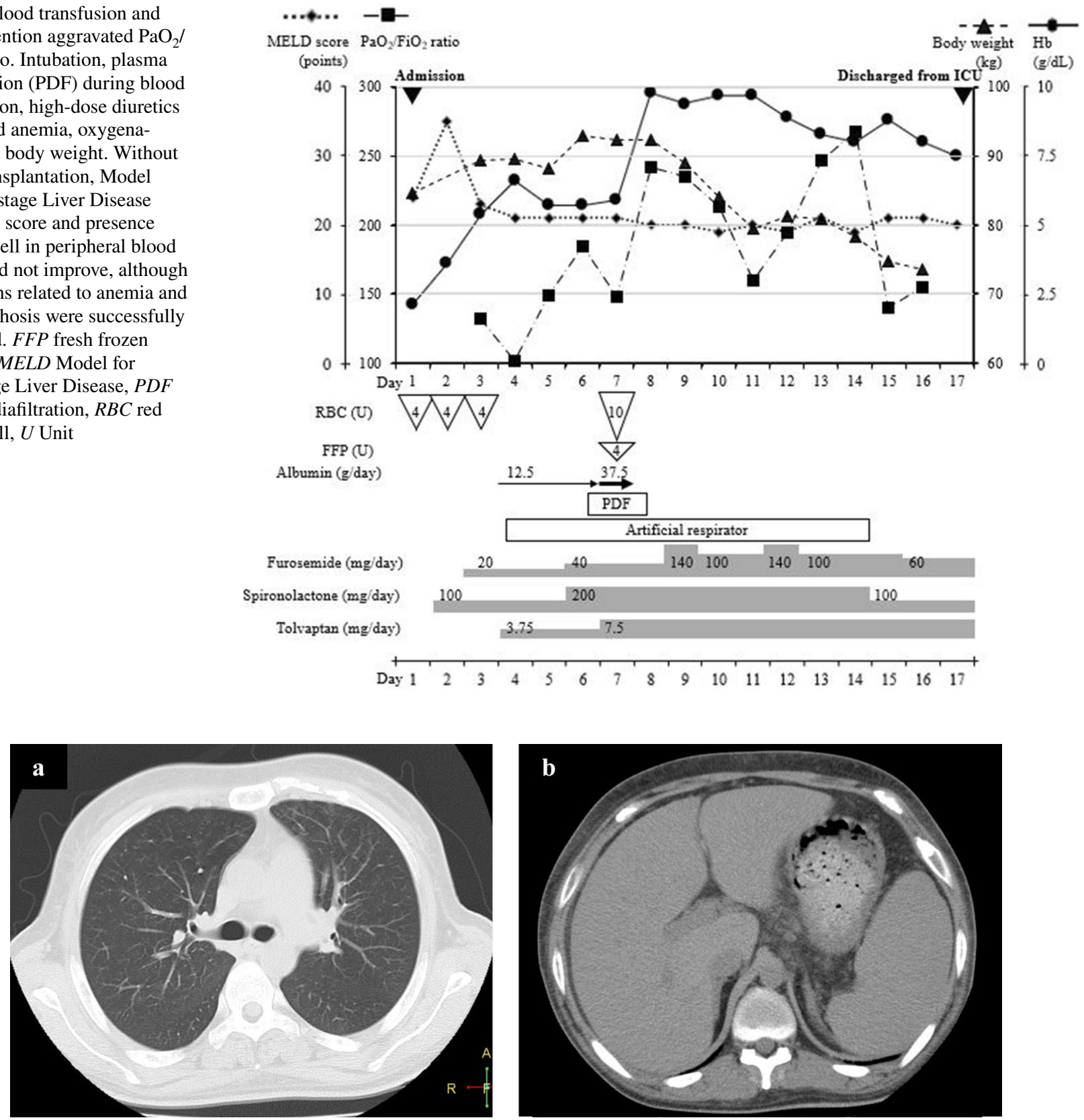

Fig. 5 a Chest computed tomography (CT) at the time of discharge revealed improvement of pleural effusion and consolidation. b Abdominal $\mathrm{CT}$ at the time of discharge showed improved subcutaneous edema. Though, there was no obvious change in liver shape

step in the diagnosis of SCA. The prevalence of SCA among patients with liver cirrhosis is still unclear. Vassiliadis et al. reported that $16.7 \%$ (9 out of 54) of patients with liver cirrhosis with a Child-Pugh score $>7$, had SCA [12]. Alexopoulou et al. reported that $31 \%$ (36 out of 116) of patients with decompensated liver cirrhosis, had SCA [22]. When compared with patients without SCA, patients with SCA had worse liver function (higher MELD score) [12, 22], lower hemoglobin levels [12], and worse survival [12, 22].
Alexopoulou et al. also reported that in multivariate analysis, SCA was an independent predictor of mortality, and survival rate of patients with SCA at the first, second, and third month of follow-up was $77 \%, 45 \%$, and $33 \%$, respectively, with a median reported survival of 1.9 months [22]. Vassiliadis et al. reported a 25-day median survival rate in the 9 patients with SCA, and only one patient, who had undergone liver transplantation, had survived after 1 year [12]. To our knowledge, there have been 24 case reports on 26 patients 
with SCA since 1983 including our case (Table 3) [13, 14, $16,19,20,23-40]$. On reviewing these cases, the average age was 42.6 years old, and $14(53.8 \%)$ of the 26 patients were men. Most of the cases lack the data of severity of liver disease, such as Child-Pugh score and Model for End-stage Liver Disease (MELD) score. Though, assessable cases had severe liver disease with average Child-Pugh score 11 points, and average MELD score 26.3 points. The average hemoglobin level was $7.5 \mathrm{~g} / \mathrm{dL}$ and our case had the lowest hemoglobin level. Patients underwent liver transplantation experienced recovery of SCA and had good prognosis. However, patients without liver transplantation had poor survival time (from 2 weeks to 5 months), except for our case (doing well for a year without aggravation of liver disease and hemoglobin level). As seen in the literature, the prognosis of SCA is extremely poor and management of SCA is essential for better survival in end stage liver cirrhosis.

As for treatment, abstinence from alcohol is required to avoid the progression of alcoholic liver cirrhosis. Liver transplantation remains the only curative treatment for reversing SCA [13-17], and very few attempts have been made for treatment without liver transplantation. Flunarizine is reported to impair the morphological abnormality of red blood cells, and two cases of SCA treated by flunarizine are reported. In addition, there has been a case of SCA that was treated by combination therapy comprising

Table 3 Characteristics of patients with spur cell anemia

\begin{tabular}{|c|c|c|c|c|c|c|c|c|c|}
\hline No & Age & Sex & Etiology & $\begin{array}{l}\text { Child- } \\
\text { Pugh } \\
\text { score }\end{array}$ & MELD score & $\begin{array}{l}\text { Hemo- } \\
\text { globin }(\mathrm{g} / \\
\mathrm{dL})\end{array}$ & Treatment & Prognosis & References \\
\hline 1 & 26 & M & Alcohol & 11 & 24 & 2.1 & $\begin{array}{l}\text { Blood transfusion, albumin } \\
\text { infusion, plasma diafiltra- } \\
\text { tion, diuretics, intubation }\end{array}$ & Doing well for a year & Our case \\
\hline 2 & 31 & M & Alcohol & NA & NA & 9.0 & Blood transfusion & Succumbed in 2 weeks & {$[23]$} \\
\hline 3 & 52 & M & Alcohol & 12 & 29 & 7.9 & $\begin{array}{l}\text { Blood transfusion, plasma- } \\
\text { pheresis, albumin infusion }\end{array}$ & Discharged & [24] \\
\hline 4 & 64 & M & NAFLD & 10 & NA & 6.6 & High-dose steroids, dialysis & Discharged & {$[25]$} \\
\hline 5 & 9 & $\mathrm{~F}$ & Wilson's disease & NA & NA & 8.9 & NA & Succumbed within 10 days & [19] \\
\hline 6 & 44 & M & Alcohol & 11 & 27 & 7.4 & NA & Waiting for LT & [26] \\
\hline 7 & 47 & $\mathrm{~F}$ & Alcohol & NA & NA & NA & Blood transfusion & NA & [27] \\
\hline 8 & 44 & $\mathrm{~F}$ & PBC/AIH overlap & NA & 30 & 9.0 & $\begin{array}{l}\text { Blood transfusion, plasma- } \\
\text { pheresis }\end{array}$ & Waiting for $\mathrm{LT}$ & [28] \\
\hline 9 & 60 & M & Alcohol & NA & 38 & 6.1 & Blood transfusion & Succumbed in 5-months & [29] \\
\hline 10 & 32 & $\mathrm{~F}$ & Alcohol, HCV & NA & NA & 6.2 & Blood transfusion & Waiting for LT & {$[30]$} \\
\hline 11 & 56 & $\mathrm{~F}$ & NA & NA & NA & 6.8 & Blood transfusion & Succumbed & {$[31]$} \\
\hline 12 & 61 & $\mathrm{~F}$ & $\mathrm{PBC}$ & NA & NA & 6.2 & NA & NA & {$[20]$} \\
\hline 13 & 34 & M & Alcohol & NA & NA & NA & LT & Doing well & [13] \\
\hline 14 & 17 & $\mathrm{~F}$ & Biliary atresia & NA & NA & 5.7 & LT & Doing well & [14] \\
\hline 15 & 47 & M & Alcohol & NA & NA & 7.3 & Blood transfusion & Waiting for LT & {$[32]$} \\
\hline 16 & 43 & $\mathrm{~F}$ & Alcohol & NA & 40 & 11.2 & NA & Succumbed in 2-months & [33] \\
\hline 17 & 48 & M & NA & NA & NA & 7.7 & NA & Succumbed before LT & [34] \\
\hline 18 & 30 & M & Alcohol & NA & NA & 7.7 & $\begin{array}{l}\text { Flunarizine, pentoxifylline, } \\
\text { cholestyramine }\end{array}$ & Recovery of anemia & {$[35]$} \\
\hline 19 & 41 & $\mathrm{~F}$ & Alcohol & NA & NA & 8.4 & Diuretics & Lost of follow-up & {$[36]$} \\
\hline 20 & 31 & M & Alcohol & NA & NA & NA & LT & Doing well a year later & [16] \\
\hline 21 & 53 & M & Alcohol & NA & NA & 8.5 & LT & Recovery of anemia & {$[37]$} \\
\hline 22 & 44 & $\mathrm{~F}$ & Alcohol & NA & NA & 9.0 & LT & Doing well 3-months later & [37] \\
\hline 23 & 49 & M & Alcohol & NA & NA & NA & NA & NA & [38] \\
\hline 24 & 52 & M & Alcohol & NA & NA & 7.9 & NA & Succumbed & [39] \\
\hline 25 & 47 & $\mathrm{~F}$ & Alcohol & NA & NA & 6.2 & Flunarizine & Recovery of anemia & [40] \\
\hline 26 & 45 & $\mathrm{~F}$ & Alcohol & NA & NA & 8.3 & Flunarizine & ND & {$[40]$} \\
\hline
\end{tabular}

$A I I H$ autoimmune hepatitis, $H C V$ hepatitis $\mathrm{C}$ virus, $F$ female, $L T$ liver transplantation, $M$ male, $M E L D$ Model for End-Stage Liver Disease, $N A$ not available, $N A F L D$ non-alcoholic fatty liver disease, $P B C$ primary biliary cholangitis 
flunarizine, pentoxifylline, and cholestyramine, although flunarizine and pentoxifylline had to be discontinued 6 months later due to adverse events [35]. High-dose steroids were also reported to be effective in improving anemia in SCA [25]. Plasmapheresis has been reported to improve dyslipidemia in SCA (increase in concentrations of total cholesterol, phospholipids, and apo-AI), and as an effective treatment of SCA [24]. However, the precise mechanism of effectiveness in these cases is still unknown, and liver transplantation is the only curative treatment to reverse the morphological feature of SCA.

In our case, acute respiratory distress syndrome occurred secondary to SCA related to alcoholic liver disease. There are several causes of acute respiratory distress syndrome considered in our case. First, there was a possibility of acuteon-chronic liver failure in our case [41]. Acute-on-chronic liver failure patients experience systematic inflammatory response syndrome because of cytokine storm in relation acute insult and/or subsequent development of sepsis [42]. In our case, blood culture remained negative, so sterile inflammation response or occult infection could be considered. However, our case was not visiting our hospital regularly and we lacked the laboratory data for the diagnosis of acuteon-chronic liver failure in Japan. Secondary, fluid retention (e.g., ascites, pleural effusion, edema) are common complications of end stage liver cirrhosis, and could cause respiratory failure. The mechanism of fluid retention in cirrhosis is complicated, although the major causes can be explained by malnutrition and increased activity in the renin-angiotensin-aldosterone system, which leads to hyperdynamic circulation $[43,44]$.
We successfully managed SCA without liver transplantation. Blood transfusion is necessary to improve oxygenation and increase the hemoglobin level. Liver transplantation is the only curative treatment of spur cell anemia. According to the Japan society of hepatology, the candidate of liver transplantation should be considered by liver function (Child-Pugh score 10 points or more, of MELD score), period of alcohol abstinence (more than 18 months), and hepatocellular carcinoma (within the Milan criteria [45] or within the 5-5-500 rule [46]). When the patient is not a candidate of liver transplantation, SCA, which could be accompanied with fluid retention, organ failure, such as liver failure, respiratory failure (aggravated by aggressive transfusion), must be managed by preserved treatment. During treatment, nutrition support for liver failure, respiratory care, including intubation, for respiratory failure, and fluid retention control, including diuretics, albumin infusion, plasma diafiltration (PDF), was helpful (Fig. 6). In addition, PDF, a blood purification therapy in which simple plasma exchange is performed using a selective plasma separator while the dialysate flows outside the hollow fibers [47], was useful in the removal of water-soluble and albumin-bound toxins [47]. The benefit of PDF compared to simplex plasma exchange is that PDF enabled the performance of dialysis simultaneously with plasma exchange, without worsening fluid retention [47].

Several limitations to our report exist. First, Japanese health care insurance does not cover PDF in chronic liver disease, and careful informed consent must, therefore, be obtained before initiating treatment. Secondary, our report luck the evaluation of cholesterol/phospholipid ratio in red
Fig. 6 Blood transfusion is necessary for the management of spur cell anemia. Liver transplantation is the only curative treatment of spur cell anemia, considered by liver function, period of alcohol abstinence, and hepatocellular carcinoma. When the patient is not a candidate of liver transplantation, nutrition support for liver failure, respiratory care, including intubation, for respiratory failure, and fluid retention control, including diuretics, albumin infusion, plasma diafiltration, was helpful for management during blood transfusion

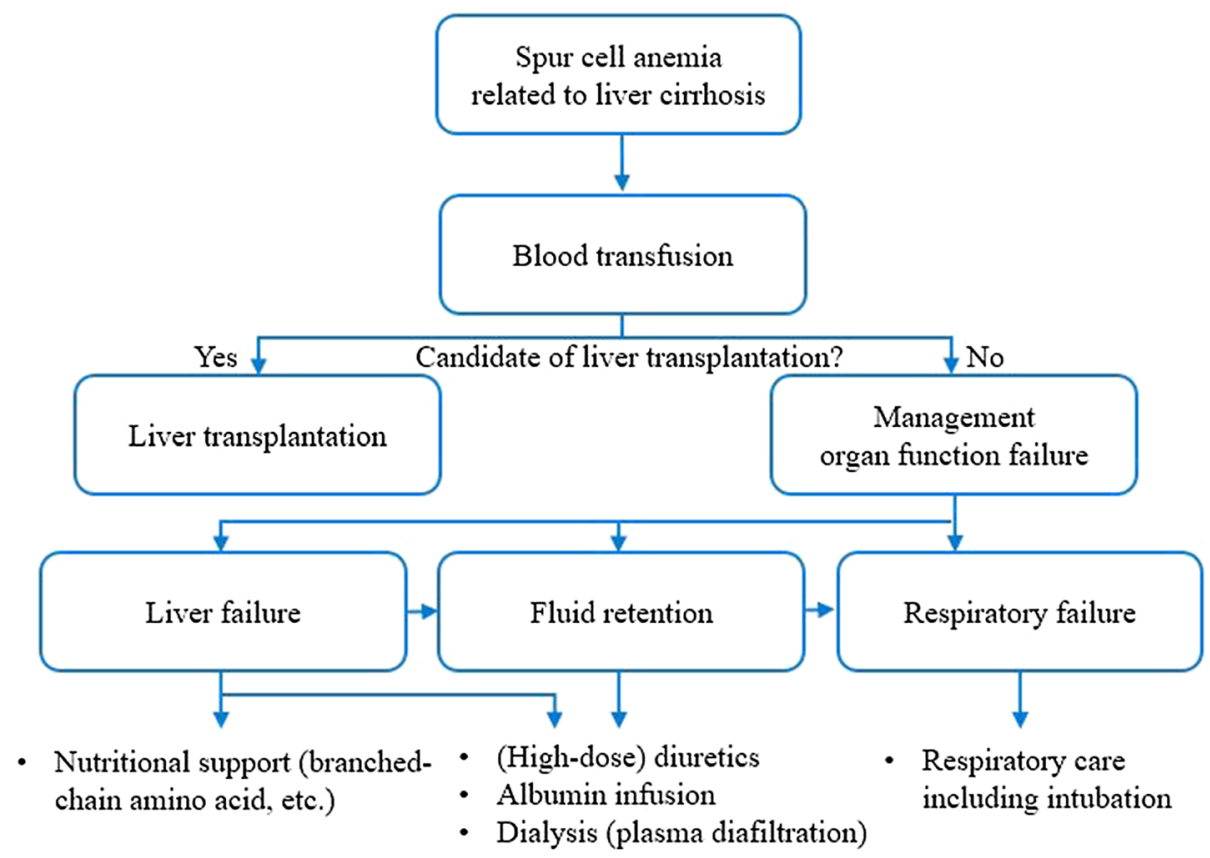


bold cell membrane, serum chenodeoxycholic acid level and serum deoxycholic + cholic acid/chenodeoxycholic acid ratio, which is observed in SCA [16]. However, recent diagnostic criteria of SCA do not include these laboratory data [22]. Finally, although our treatment strategies successfully managed severe SCA with alcoholic liver cirrhosis, SCA could not be reversed without liver transplantation. Liver transplantation is essential in severe SCA accompanied by worse liver function as curative treatment, and clinicians should look for the possibility of liver transplantation in candidates of liver cirrhosis. Our managing strategies might be useful in patients with SCA who is not a candidate of liver transplantation or patients waiting for liver transplantation.

In conclusion, blood transfusion and control of fluid retention were successful in managing SCA related to alcoholic liver cirrhosis. This finding, which is dependent on the assumption of abstinence from alcohol, warrants further investigations for the management of SCA without liver transplantation.

Acknowledgements Authors would like to appreciate Dr. Shigeru Akamatsu and Dr. Keitaro Watanabe for his clinical support, Dr. Naoki Mita for his academic support. This research did not receive any specific grant from funding agencies in the public, commercial, or notfor-profit sectors.

Author contributions TM treated the patient and wrote the paper; YH evaluated pathologically; TK, MA, KT, HG, NN, NK, and KI supervised the treatment; MS mainly reviewed and amended the manuscript; all authors issued final approval for the version to be submitted.

\section{Compliance with ethical standards}

Conflict of interest Takao Miwa, Yuichiro Hatano, Takahiro Kochi, Masashi Aiba, Katsuhisa Toda, Hideko Goto, Noriaki Nakamura, Naoki Katsumura, Kenji Imai, and Masahito Shimizu declare that they have no conflict of interest.

Human and animal rights All procedures followed have been performed in accordance with the ethical standards laid down in the 1964 Declaration of Helsinki and its later amendments.

Informed consent Informed consent was obtained from the patient for publication of this case report.

\section{References}

1. Li J, Han B, Li H, et al. Association of coagulopathy with the risk of bleeding after invasive procedures in liver cirrhosis. Saudi J Gastroenterol. 2018;24:220-7.

2. Drolz A, Horvatits T, Roedl K, et al. Coagulation parameters and major bleeding in critically ill patients with cirrhosis. Hepatology. 2016;64:556-68.

3. Kalafateli M, Triantos CK, Nikolopoulou V, et al. Non-variceal gastrointestinal bleeding in patients with liver cirrhosis: a review. Dig Dis Sci. 2012;57:2743-54.
4. Gkamprela E, Deutsch M, Pectasides D. Iron deficiency anemia in chronic liver disease: etiopathogenesis, diagnosis and treatment. Ann Gastroenterol. 2017;30:405-13.

5. Gonzalez-Casas R, Jones EA, Moreno-Otero R. Spectrum of anemia associated with chronic liver disease. World J Gastroenterol. 2009;15:4653-8.

6. Hanai T, Naiki T, Takamatsu M, et al. A case of acute autoimmune hepatitis associated with autoimmune hemolytic anemia. Nihon Shokakibyo Gakkai zasshi. 2013;110:1814-22.

7. Dziezyc-Jaworska K, Litwin T, Czlonkowska A. Clinical manifestations of Wilson disease in organs other than the liver and brain. Ann Transl Med. 2019;7:S62.

8. Gremida A, Paleti S, Perez ET, et al. Hemolysis in alcoholic liver disease: Zieve's syndrome. Dig Dis Sci. 2018;63:601-4.

9. Smith JA, Lonergan ET, Sterling K. Spur-cell anemia: hemolytic anemia with red cells resembling acanthocytes in alcoholic cirrhosis. N Engl J Med. 1964;271:396-8.

10. Rauff B, Idrees M, Shah SA, et al. Hepatitis associated aplastic anemia: a review. Virol J. 2011;8:87.

11. Stickel F, Hoehn B, Schuppan D, et al. Review article: nutritional therapy in alcoholic liver disease. Aliment Pharmacol Ther. 2003;18:357-73.

12. Vassiliadis T, Mpoumponaris A, Vakalopoulou S, et al. Spur cells and spur cell anemia in hospitalized patients with advanced liver disease: incidence and correlation with disease severity and survival. Hepatol Res. 2010;40:161-70.

13. Gerber B, Stussi G. Reversibility of spur cell anemia. Blood. 2011;118:4304.

14. Alkhouri N, Alamiry MR, Hupertz V, et al. Spur cell anemia as a cause of unconjugated hyperbilirubinemia after liver transplantation and its resolution after retransplantation. Liver Transpl. 2011;17:349-50.

15. Malik P, Bogetti D, Sileri P, et al. Spur cell anemia in alcoholic cirrhosis: cure by orthotopic liver transplantation and recurrence after liver graft failure. Int Surg. 2002;87:201-4.

16. Chitale AA, Sterling RK, Post AB, et al. Resolution of spur cell anemia with liver transplantation: a case report and review of the literature. Transplantation. 1998;65:993-5.

17. Nakatsuka H, Sato $Y$, Oya H, et al. A case of spur cell anemia resolved by living donor liver transplantation. Kanzo. 2007;48:181-6.

18. Cooper RA, Jandl JH. The role of membrane lipids in the survival of red cells in hereditary spherocytosis. J Clin Investig. 1969;48:736-44.

19. Soni K, Kotru M, Dewan P, et al. Spur cell anemia in Wilson's disease: a rare presentation. Int J Lab Hematol. 2017;39:e64-e6565.

20. Martin M, Lesesve JF. Transfusion medicine illustrated. Spur cell anemia associated with primary biliary cirrhosis. Transfusion. 2013;53:260.

21. Haruta I, Hashimoto E, Kabutake A, et al. Spur cell anemia associated with a cirrhotic non-alcoholic steatohepatitis patient. Hepatol Res. 2007;37:482-5.

22. Alexopoulou A, Vasilieva L, Kanellopoulou T, et al. Presence of spur cells as a highly predictive factor of mortality in patients with cirrhosis. J Gastroenterol Hepatol. 2014;29:830-4.

23. Keyserling K, Koprowski S. Spur-cell anemia. N Engl J Med. 2018;379:774.

24. Miki K, Maruki T, Imashuku S. Plasmapheresis for Spur cell anemia in a patient with alcoholic liver cirrhosis. Case Rep Hematol. 2018. https://doi.org/10.1155/2018/9513946.

25. Karam D, Swiatkowski S, Purohit P, et al. High-dose steroids as a therapeutic option in the management of spur cell haemolytic anaemia. BMJ Case Rep. 2018. https://doi.org/10.1136/bcr-2017223281. 
26. Privitera G, Spadaro L, Marchisello S, et al. Abnormalities of lipoprotein levels in liver cirrhosis: clinical relevance. Dig Dis Sci. 2018;63:16-26.

27. Murphy CH, Jain S, Sabath DE, et al. Spur cell hemolytic anemia in liver failure. Transfusion. 2016;56:787-8.

28. Partain DK, Botero JP, Shi M, et al. Spur cell anemia in the setting of progressive liver allograft failure. Am J Hematol. 2016;91:1061.

29. Zimmer V, Bittenbring J, Fries P, et al. Severe mixed-type iron overload in alcoholic cirrhosis related to advanced spur cell anemia. Ann Hepatol. 2014;13:396-8.

30. Shah R, Patel A, John S. Spur cell anemia in end-stage liver disease: a zebra! Am J Emerg Med. 2014;32(944):e3-4.

31. Sugimoto S, Yamagishi Y, Ebinuma H, et al. Spur cell anemia associated with alcoholic cirrhosis. Intern Med. 2013;52:2831.

32. Goel A, Kumar JD, Nair S, et al. Education and imaging. Hepatobiliary and pancreatic: spur cell anemia associated with alcoholic cirrhosis. J Gastroenterol Hepatol. 2008;23:1463.

33. Sundaram V, Al-Osaimi AM, Lewis JJ, et al. Severe prolongation of the INR in spur cell anemia of cirrhosis: true-true and related? Dig Dis Sci. 2006;51:1203-5.

34. Martin M, de Las HD. Spur-cell anaemia in a patient with cirrhosis. J Hepatol. 2004;41:167.

35. Aihara K, Azuma H, Ikeda Y, et al. Successful combination therapy-flunarizine, pentoxifylline, and cholestyramine-for spur cell anemia. Int J Hematol. 2001;73:351-5.

36. Ricard MP, Martinez ML, Ruiz J. Spur cell hemolytic anemia of severe liver disease. Haematologica. 1999;84:654.

37. Thomson A, Kerlin P, Clouston A, et al. Spur cell anaemia resolves after orthotopic liver transplantation (OLT). Aust N Z J Med. 1997;27:198-9.

38. Marshall AT, Waxman I. Image of the month. Spur cell anemia. Gastroenterology. 1997;112(326):673.
39. Olivieri O, Guarini P, Negri M, et al. Increased proteolytic activity of erythrocyte membrane in spur cell anaemia. Br J Haematol. 1988;70:483-9.

40. Fossaluzza V, Rossi P. Flunarizine treatment for spur cell anaemia. Br J Haematol. 1983;55:715-7.

41. Mochida S, Nakayama N, Ido A, et al. Proposed diagnostic criteria for acute-on-chronic liver failure in Japan. Hepatol Res. 2018;48:219-24.

42. Sarin SK, Choudhury A. Management of acute-on-chronic liver failure: an algorithmic approach. Hepatol Int. 2018;12:402-16.

43. Pose E, Cardenas A. Translating our current understanding of ascites management into new therapies for patients with cirrhosis and fluid retention. Dig Dis. 2017;35:402-10.

44. Sam J, Nguyen GC. Protein-calorie malnutrition as a prognostic indicator of mortality among patients hospitalized with cirrhosis and portal hypertension. Liver Int. 2009;29:1396-402.

45. Mazzaferro V, Regalia E, Doci R, et al. Liver transplantation for the treatment of small hepatocellular carcinomas in patients with cirrhosis. N Engl J Med. 1996;334:693-9.

46. Shimamura T, Akamatsu N, Fujiyoshi M, et al. Expanded livingdonor liver transplantation criteria for patients with hepatocellular carcinoma based on the Japanese nationwide survey: the 5-5-500 rule-a retrospective study. Transpl Int. 2019;32:356-68.

47. Nakae H, Eguchi Y, Saotome T, et al. Multicenter study of plasma diafiltration in patients with acute liver failure. Ther Apher Dial. 2010;14:444-50.

Publisher's Note Springer Nature remains neutral with regard to jurisdictional claims in published maps and institutional affiliations. 